\title{
Protein and fat composition and vitamin content of Boletus (Suillus) luteus mycelium produced in submerged culture
}

\author{
Marja Liisa Hattula and H. G. Gyllenberg \\ Department of Microbiology, University of Helsinki
}

Man has utilized fungi as food for centuries. Agaricus spp. and Boletus spp. of the Basidiomycetes and Morchella spp., the morel mushrooms of the Ascomycetes have been the most common types consumed (LiTCHFIELD, 1964). The idea of growing fungi for their mycelium rather than their fruiting bodies developed because of, or at least was stimulated by, the success of deep tank or submerged fermentation in the field of the large scale production of antibiotics (RoBInson \& Davidson, 1959). Man has grown various microorganisms on an industrial scale since World War I when yeasts were produced to supply a source of dietary fats in Germany. During World War II several kinds of microorganisms were grown for human food purposes. Food preparations were made from strains of Fusarium, Candida, Oospora, Endomyces and Rhizopus. The main purpose was to produce fats and protein. There is one particular reason, however, why fungal mycelium can be given preference to other microbial preparations. The edibilities of different fungi are known by tradition and experience, and moreover there is no religious taboo against fungi. Thus, if a natural prejudice toward new and unusual food materials can be overcome, there seems to be no reason why the use of fungi for food should not increase repidly (Gilbert \& Robinson, 1957).

Over the past 20 years a number of investigators have directed their attention toward the mass propagation of fungal myce- lium in submerged culture. Agaricus campestris was the first fungus which was intensively investigated. Humfeld (1948, 1952), Humfeld \& Sugihara $(1949,1952)$, Sugihara \& Humfeld (1954) etc. have investigated the growth factors and methods of growing $A$. campestris. JENNISON and his co-workers (1955, 1957) investigated the submerged cultivation of 42 different kinds of fungi. In a series of patents Szuecs and Yonkers (1950, $1954,1956,1958$ ) disclosed methods for producing essence of fungal mycelium in submerged culture and for enhancing the flavor of the mycelium. The main trend in present day research in this field seems to be mycelium production as a source of flavor rather than as a source of protein.

In this paper experiments on submerged cultivation of Boletus (Suillus) luteus are described. Boletus luteus is a quite common mushroom in Finland but its great water content and its susceptibility to insect larvae make it less acceptable (RautavaAra, 1947). The taste of the mushroom is slightly sour and the smell recalls that of fruits (HintikкA \& SAINIO, 1942). The main purpose of this investigation was to develop methods for growing the mycelium of Boletus luteus in submerged culture and to compare the vitamin, fat and protein content with the corresponding values of the fruiting bodies. Boletus luteus was selected as the test organism because it seemed to be rather easy to grow in big laboratory fermentors (14 liters). Later experiments (cf. Hattula \& Gyllen- 
BERG, 1969) have shown that a number of other fungi show better adaptability to submerged growth.

Materials, methods and results

Cultural methods: The culture used in the submerged growt experiments was kindly supplied by Professor P. Mikola (Dept. of Silviculture, University of Helsinki). The stock culture of Boletus luteus was grown on agar slant of the Modess' agar (Modess, 1941), the composition of which is presented in the accompanying paper (HatTula \& GyllenBerg, 1968).

Two agar slants of B. luteus (2 weeks old) were inoculated into $80 \mathrm{ml}$ of sterile $5 \%$ malt extract in a $250 \mathrm{ml}$ Erlenmeyer flask. The flask was incubated one week in a rotary shaker operated at $280 \mathrm{rpm}$. The grown mycelium was washed with sterile destilled water and was transferred to a 2 liter fermentor. In the two-liter fermentor one liter of Reusser's synthetic medium (Reusser \& al. $1958 \mathrm{a}$; for the composition of this medium cf. Hattula \& Glyllenderg, 1969) was used. The aeration rate was one liter air $/ \mathrm{min} / 1$ medium; agitation was $300 \mathrm{rpm}$ and the temperature $28^{\circ} \mathrm{C}$. After one week the mycelium was transferred into a 14 liter fermentor which contained 101 of Reusser's synthetic medium. Aeration was adjusted to 0.8 vol. air $/ \mathrm{min} /$ vol. of the medium, agitation was $280 \mathrm{rpm}$ and the temperature kept at $28^{\circ} \mathrm{C}$. Synthetic Naphco was used as antifoam. The growth was controlled by taking daily samples for determination of sugar (Bertrand-method; Grossfeld, 1935) and ammonium nitrogen (Conway method; Cionway, 1957). When all the sugar was consumed, 91 of the culture was removed and one liter was left at the bottom of the vessel as inoculum. New sterile medium was conducted into the fermontor, and this was repeated four times. The mycelium was separated by Büchnerfiltration and was washed with distilled water. The mycelium was then dried at $40^{\circ} \mathrm{C}$ and the dry material as ground to fine powder. The colour of the fresh mycelium was white and the aroma pleasant. The dry powder was yellow and almost odourless.

Fruiting bodies of Boletus luteus were collected from a pastureland for comparison; the were scraped clean of sand and dried at $40^{\circ} \mathrm{C}$ until they were eisy to grind to fire powder. The powder, the colour of which was dark brown, was kept in a closed vessel in the refrigerator.

\section{Analytical methods}

The vitamins:

Of the water soluble vitamins thiamine, riboflavin, nicotinic acid and vitamin $B_{12}$ were analysed quantitatively and of the fat soluble vitamins vitamin $\mathrm{D}$ was determined.

Thiamine was extracted according to the method of A.O.A.C. (39 025, 1960 a). The solution was refined free from other fluorescent compounds according to Strohegker \& Henning (1963 a). The determination was made by the A.O.A.C. method (39.025, 1960 a). The thiamine content of the mycelium was $12.3 \mu / \mathrm{g}$ dry mycelium and that of the fruiting $4 \mu \mathrm{g} / \mathrm{g}$ dry powder.

Riboflavin was extracted according to the method of A.O.A.C. (39 033, 1960 b). The method of Strohecker \& Henning (1963 b) was used for refining the solution. The determination of the vitamin was performed according to the method of A.O.A.C. (39 033, 1960 b). The riboflavin content of the mycelium was $41.0 \mu \mathrm{g} / \mathrm{g}$ dry mycelium and the corresponding value for the fruiting body was $57.0 \mu \mathrm{g}$.

Nicotinic acid (Niacin and Nicotinamide) was determined according to the method of A.O.A.C. (39 037, 39.038, $1960 \mathrm{c})$. The nicotinic acid content of the mycelium was $214 \mu \mathrm{g}$ whereas the content of the fruiting body was $1560 \mu \mathrm{g} / \mathrm{g}$ dry powder.

Determination of the vitamin $B_{12}$ was made using a microbiological method with Escherichia coli (Diding 1952). The extraction of the vitamin from the material was performed according to the method of Strohecker \& Henning (1963 c). The vitamin $B_{12}$ content of the fruiting body was found to be $55 \mathrm{m \mu g} / \mathrm{g}$ and the corresponding vitamin $\mathrm{B}_{12}$ content of the mycelium $62 \mathrm{~m} \mu \mathrm{g} / \mathrm{g}$ dry powder. The analytical data concerning the water soluble vitamins are summarized in Table 1.

Table 1. The water soluble vitamins of Boletus luteus. Vitamin content $\mu \mathrm{g} / \mathrm{g}$ dry mushroom.

$\begin{array}{lcc}\text { Vitamin } & \text { Mycelium } & \text { Fruiting body } \\ \text { Thiamine } & 12.3 & 4.0 \\ \text { Riboflavin } & 41.0 & 57.0 \\ \text { Nicotinic acid } & 214.0 & 1560.0 \\ \text { Vitamin } B_{12} & 0.062 & 0.055\end{array}$


The fat soluble vitamins were extracted from the unsaponified fraction of the fat according to Paech \& Tracey (1955). The qualitative analysis was made by thin layer chromatography (STAHL, 1962). Only the vitamin $D$ was analyzed quantitatively. In the mycelium as well as in the fruting bodies small amounts of $\beta$-carotene were detected. The attempts to demonstrate the presense of $\alpha^{-}$ tocopherol and vitamin $\mathrm{K}$ failed. The vitamin $\mathrm{D}$ was analyzed quantitatively according to STrohecker \& Henning (1963 d). The vitamin D content of the mycelium was $2.2 \mu \mathrm{g} / \mathrm{g}$ dry mycelium compared with the $9.2 \mu \mathrm{g} / \mathrm{g}$ dry fruiting body.

Fats: The total fat of the mycelium and the fruiting body preparations was extracted according to the method of A.O.A.G. (22 032, 1960 d). The rough analysis of the fat was made by thin layer chromatography (HatrulA, 1965). The following lipid fractions were found in both preparations: phospholipids, sterols, triglycerides, free fatty acids and sterolesters. Although some difference in the fatty acid composition of these fractions occured the total fatty acid composition (of the unfractionated fat) may provide a representative picture. The fatty acid methyl esters were analyzed using a Perkin Elmer Gas Chromatograph. The results concerning the total fatty acid composition of Boletus luteus are given in Table 2. The fatty acid composition of yeasts cultivated on mineral oil hydrocarbons is represented for comparison.

Table 2. The fatty acid composition of Boletus luteus compared with the fatty acid composition of yeasts cultivated on mineral oil hydrocarbons.

$\begin{array}{lccc}\text { Fatty acid } & \begin{array}{c}\text { Boletus } \\ \text { mycelium }\end{array} & \begin{array}{c}\text { luteus } \\ \text { fruiting } \\ \text { body }\end{array} & \begin{array}{c}\text { Yeasts } \\ \text { (AlENTYEVA } \\ \text { \& al., } 1968)\end{array} \\ \mathrm{C}_{10}-\mathrm{C}_{13} & 8.5 & 0.8 & 0.3 \\ \mathrm{C}_{14}: 0 & 3.6 & 0.1 & 0.1 \\ \mathrm{C}_{14}: 1 & - & - & 0.1 \\ \mathrm{C}_{15} & 2.8 & 0.5 & 3.2 \\ \mathrm{C}_{16} & 14.8 & 10.6 & 14.5 \\ \mathrm{C}_{16}: 1 & 1.3 & 1.7 & 3.7 \\ \mathrm{C}_{17}: 0 & 1.7 & 0.4 & 26.3 \\ \mathrm{G}_{17}: 1 & - & - & 23.2 \\ \mathrm{C}_{18} & 7.5 & 19.3 & 9.1 \\ \mathrm{C}_{18}: 1 & 20.4 & 16.9 & 14.7 \\ \mathrm{C}_{18}: 2 & 22.6 & 29.1 & 4.3 \\ \mathrm{C}_{19} & 1.6 & 0.8 & \\ \mathrm{C}_{18}: 3 & 0.4 & - & \\ \text { unidentified } & 18.3 & 19.8 & 0.5 \\ \text { Total \% } & 100.0 & 100.0 & 100.0\end{array}$

Table 3. The amino acid content of Boletus luteus compared with the amino acids of potato, beef and algae (Spirulina maxima). Gram of amino acid/16 gram of nitrogen.

\begin{tabular}{|c|c|c|c|c|c|}
\hline Amino acid & \multicolumn{2}{|c|}{$\begin{array}{l}\text { Boletus luteus } \\
\text { fr. body mycel. }\end{array}$} & $\begin{array}{l}\text { Potato } \\
\text { (Belitz }\end{array}$ & $\begin{array}{l}\text { Beef } \\
\text { SGHORMÜLLER, } \\
\text { 967) }\end{array}$ & $\begin{array}{c}\text { Spirulina maxima } \\
\text { (CLÉment \& al., } \\
1967 \text { ) }\end{array}$ \\
\hline Aspartic acid & 6.06 & 7.15 & 11.5 & $9.7-9.9$ & 8.60 \\
\hline Threonine & 3.39 & 3.60 & 2.5 & 4.8 & 4.56 \\
\hline Serine & 3.47 & 3.88 & 2.6 & $4.1-4.5$ & 4.20 \\
\hline Glutamic acid & 10.52 & 8.50 & 7.4 & $15.8-16.2$ & 12.60 \\
\hline Proline & 3.43 & 3.23 & 3.0 & $3.0-4.1$ & 3.90 \\
\hline Glycine & 3.59 & 3.61 & 1.9 & $4.6-6.1$ & 4.75 \\
\hline Alanine & 4.26 & 4.89 & 6.1 & $6.1-6.3$ & 6.80 \\
\hline Valine & 0.13 & - & 4.3 & $4.8-5.5$ & 6.49 \\
\hline Cystine & 4.02 & 5.87 & 0.6 & $1.3-1.5$ & 0.40 \\
\hline Methionine & 0.18 & 1.08 & 2.5 & $4.1-4.5$ & 1.37 \\
\hline$\alpha$ - $\varepsilon$-diaminopimelic acid & 20.02 & 15.46 & & & \\
\hline Isoleucine & 6.39 & - & 5.9 & 5.2 & 6.03 \\
\hline Tyrosine & 2.47 & 3.86 & 2.5 & $3.8-4.0$ & 8.02 \\
\hline Phenylalanine & 2.63 & 4.25 & 3.6 & $3.8-4.5$ & 4.97 \\
\hline$\gamma$-aminobutyric acid & 4.69 & 1.16 & & & \\
\hline Ornithine & 0.30 & 0.30 & & & \\
\hline Lysine & 2.67 & 8.39 & 3.7 & $9.2-9.4$ & 4.59 \\
\hline Tryptophan & 1.74 & 3.72 & 1.0 & - & 1.40 \\
\hline Histidine & 2.15 & 2.35 & 1.2 & $3.7-3.9$ & 1.77 \\
\hline Arginine & 4.18 & 4.70 & 7.1 & $5.3-5.5$ & 6.50 \\
\hline Ammonia & 11.58 & 8.21 & & & 1.24 \\
\hline
\end{tabular}


Amino acids: Only the total amino acids of Boletus luteus were analyzed; the free amino acids were not analyzed separately. An Autoanalyzer (Technicon) was used for the determinations and the preparative and analytical methods are described in detail in the accompanying paper of HATtula and Gyllenberg (1969).

Table 3 shows the total amino acid composition of Boletus luteus. Some data referring to the amino acid compostion of vegetable, animal and microbial protein have been included for comparison.

\section{Discussion}

The main components of Boletus luteus are summarized in Table 4 . The results show that the carbohydrates cannot be considered of great nutritional value because of their small amount. As to the fatty acid composition of $B$. luteus, the high content of linolic acid contributes significantly to the nutritional value. The results for amino acids given in Table 3 show that both the fruiting body

Table 4. The main components of dried Boletus luteus.

$\begin{array}{lcc}\text { Component } & \text { Fruiting bodies } & \text { Mycelium } \\ \text { Carbohydrates } & & \\ \text { (soluble) } & 5.00 & 5.15 \\ \text { Fats } & 5.50 & 4.30 \\ \text { Protein }(\mathrm{N} \times 6.25) & 24.60 & 23.80 \\ \text { Moisture } & 3.44 & 6.51 \\ \text { Ash } & 5.85 & 4.25 \\ \text { Insoluble material } & & \\ \text { (cellulose, etc.) } & 55.61 & 55.99 \\ \text { Total \% } & 100.0 & 100.0\end{array}$

and the mycelium are comparable to good vegetable and animal protein except for valine and methionine. The amount of cystine is, however, remarkably high and cystine can substitute for methionine in the diet up to $80 \%$. Accordingly, the low valine content is the only real deficiency of $B$. luteus protein. However, in the mycelium of Boletus luteus no isoleucine could be detected, but the amount of this amino acid was sufficient in the fruiting body. The amounts of leucine, phenylalanine, lysine and tryptophan are high enough in the mycelium of this fungus but in the fruiting body the amounts of lysine and leucine are quite small. On the whole the amino acid content can be regarded good. The contents of different water soluble vitamins in Boletus luteus are good. $100 \mathrm{~g}$ dry mycelium contains the same amount of thiamine as $220 \mathrm{~g}$ pork or $250 \mathrm{~g}$ wheat meal (whole grain). As to the riboflavin content of the mushroom $100 \mathrm{~g}$ of the dry fruiting body corresponds to $370 \mathrm{~g}$ pork or $190 \mathrm{~g}$ veal (Turpeinen \& Roine, 1967). The amount of nicotinic acid is also considerable.

In our opinion Boletus luteus seems to constitute a good supplement for other foods, especially with regard to the protein and the water soluble vitamin content of the mushroom. Moreover, it is obvious that the submerged cultivation of mycelium does not cause losses in nutritionally valuable constituents as compared with the fruiting bodies produced under natural conditions. In fact, as shown above, the artificially grown mycelium, in certain respects may possess an even higher nutritional value.

\section{REFERENGES :}

Alentyeva, E. S., E. N. Zhdannikova, \& L. I., Kozlova, 1968: Composition and properties of lipids of yeasts cultivated on oil hydrocarbons, 4th international symposium on continuous cultivation of microorganisms, Prague.

Association of Official Agricultural Chemists, 1960: Ninth edition, A.O.A.C., P.O. Box B, Franklin Station, Washington 4 D.G. a) 657 658 , b) $658-660$, c) 660 , d) 287.

Belitz, H. D. \& J. Schormüller, 1965: Aminosäuren, Peptide usw. Handbuch der Lebensmittelchemie, Springer Verlag, Berlin, Heidelberg, New York, 271-277.

Block, S. S., F. W. Stearns, R. L. Stephens \& R. F. J. Mc Candless, 1953, Mushroom mycelium, experiments with submerged culture, J. Agr. Food Chem. 1, 890-893.
Grrillo, V. P., W. A. Crestwood, O. Hardwiak \& R. D. SEeley, 1960: Fermentation process for producing edible mushroom mycelium, U.S. Patent 2928210.

Clément. G., G. Ciddey \& R. Menzi, 1967: Amino acid composition and nutritive value of the alga Spirulina maxima, J. Sci Fd. Agric, 18, 497-501.

Conway, E. J., 1957: Microdiffusion analysis, 4th edition, Crosby Lockwood \& Son Ltd, London, 465.

Diding, N. Å., 1952: Svensk farmaceutisk tidskrift, 56, 160-170. Methods of Vitamin Assay, New York, 1951.

Falanghe, H., 1962: Production of mushroom mycelium as a protein and fat source in submerged culture in medium vinasse. Appl. Microbiol., 10, 572-575. 
Gilbert, F. A. \& R. F. Robinson 1957: Food from fungi, Economic Botany, 11, 126-145.

Grossfeld, J., 1935: Kohlenhydrate in Handbuch der Lebensmittelchemie, ed. A. Böhmer, Springer Verlag, Berlin III, 2, 866-868.

Hattula, M. L., 1965: Eläinkudoksesta eristettyjen rasvahappojen kaasukromatografiaa, Pro gradu, Helsingin Yliopisto, 65-69.

Hattula, M. L. \& H. G. Gyllenberg, 1969: Adaptability to submerged culture and amino acid contents of certain fungi common in Finland Karstenia IX, 39-45.

Hintikka, T. I. \& A. Sarnio, 1942: Sienikirja, Valistus, Helsinki, 32.

Humfeld, H., 1948: The production of mushroom mycelium (Agaricus campestris) in submerged culture, Science, 107, 373.

Humfeld, H., 1952: Production of mushroom mycelium, U.S. Patent 2618000.

Humfeld, H. \& T. F. Sugihara, 1949: Mushroom mycelium production by submerged propagation, Food Technol. 3, 355-356.

Humfeld, H. \& T. F. Sugihara, 1952: The nutrient requirements of Agaricus campestris grown in submerged culture, Mycologia, 44, 605620.

Jennison, M. W., M. D. Newcomb \& R. Henderson, 1955: Physiology of the wood rotting Basidiomycetes. I. Growth and nutrition in submerged culture in synthetic media, Mycologia, 47, 275-304.

Jennison, M. W., C. Reichberg \& A. E. Krikszens, 1957: Physiology of the wood rotting Basidiomycetes II. Nutritive composition of mycelium grown in submerged culture, Appl. Microbiol., 5, 87-95.

Litchifield, J. H., 1964: The mass cultivation of Morchella species in submerged culture and their potential uses as a source of protein. In Clobal Impacts of Applied Microbiology, Almqvist \& Wiksell, Upsala, 327-337.

LitchField, J. H., 1967 a: Submerged culture of mushroom mycelium. Microbial Techonology, Reinhold Publishing Corporation, New York, Amsterdam, London, 107-144.

Litchfiesd, J. H., 1967 b: Submerged culture of mushroom mycelium, Food Technol, 21, $55-57$.

Litchfield, J. H., R. C. Overbeck \& R. S. DAvidson, 1963: Factors affecting the growth of morel mushroom mycelium in submerged culture, Agr. Food Chem., 11, 158-162.

Modess, O., 1941: Zur Kentniss der Mykorrhizabildner von Kiefer und Fichte, Symb. bot. upsal., V 1:1, 16.

Paech, K. \& M. V. Tracey, 1955: Moderne Methoden der Pflanzenanalyse, Springer Verlag, Berlin-Göttingen-Heidelberg, 279 -282 .

Rautavaara, T., 1947: Suomen sienisato, Porvoo, $503-504$.

Reusser, F., I. F. T. Spencer \& H. R. Sallans, 1958 a: Protein and fat content of some muschrooms grown in submerged culture, Appl. Michobiol., 6, 1-4.

Reusser, F. I. F. T. Spencer \& H. R. Sallans, 1958 b: Tricholoma nudum as a source of protein, Appl. Microbiol., 6, 5-8.

Robinson, R. F. \& R. S. Davidson, 1959: The large scale growth of higher fungi, Advances in Appl. Microbiol., 1, 261-277.

STAHL, E., 1962: Dünnschicht Chromatographie, Springer Verlag, Berlin, Göttingen, Heidelberg, $220-222$.

Strohecker, R. \& H. M. Henning, 1963: Vitamin-Bestimmungen, Verlag Chemie $\mathrm{GmbH}$, Weinheim/Bergstr., a) $73-75$, b) 108 , c) 170 , d) $265-267,278-288$.

Sugrhara, T. F. \& H. Humfeld, 1954: Submerged culture of the mycelium of various species of mushroom, App. Microbiol., 2, 170-172.

Szuecs, J., 1954: Method of enhancing mushroom mycelium flavor, U.S. Patent 2693664.

Szuecs, J., 1950: Essence of mushroom and its preparation, U.S. Patent, 2505811.

Szuecs, J., 1956: Mushroom culture, U.S. Patent 2761246.

Szuecs, J., 1958: Method of growing mushroom mycelium and the resulting products, U.S. Patent 2850841.

Turpeinen, O. \& P. Roine, 1967: Ruoka-ainetaulukko, 8. painos, Otava, Helsinki, 12, 3235 . 